\title{
Predikce průtoků modelem SWAT na prríkladu povodí vodního díla Olešná
}

\section{PETR KRPEC}

\author{
Klíčová slova: model SWAT- vstupní data - vodní nádrž Olešná - kalibrace a validace
}

\section{SOUHRN}

Př́spěvek je zaměřen na posouzení výsledků simulace průtoků komplexním modelem SWAT, který je obtížný pro užívání z hlediska potřeby vstupních dat o půdách a managementu povodí. Na príkladu povodí VD Olešná, které patři mezi menší povodí, než je běžné pro používání SWATu, byla provedena kalibrace vybraných parametrů při srovnání s měřenými daty a následně validace kalibrovaného modelu na validační pozorované řadě. Model má v tomto př́padě problém s predikcí denních průtoků spojený s většími srážkovými událostmi, měsíční průtoky pak predikuje velmi dobře. Model je velmi vhodný především pro posouzení dopadu různých scénářu (klimatické změny, využivání krajiny $v$ povodí apod.) v dlouhodobém časovém měřítku. Další rozvoj modelu je plánován pro kalibraci parametrů modelu pro predikci transportu živin z povodí do nádrže.

\section{ÚVOD}

Matematické modely se $v$ hydrologii uplatňuji již řadu let ruku v ruce s rostoucím výkonem výpočetní techniky a dostupností vstupních dat. Umožňují realizaci virtuálních experimentů, které Ize empiricky provést bud' jen velmi obtížně, nebo vůbec. V praxi se využívají ke studiu hydrologických procesů a odhadům dopadu různých scénárư na hydrologické procesy. Základním předpokladem je, aby zvolený model dostatečně realisticky simuloval potřebné procesy pro minimalizaci nejistoty výsledků. Především v současné době, ve které potřebujeme plánovat účinná opatření v krajině k adaptaci na probíhající klimatické změny, může být role těchto modelů pro posouzení efektivity adaptačních opatření nezastupitelná. Především v simulacích procesů v zemědělsky využivaných povodích je široce uplatňován model SWAT (akronym pro Soil and Water Assessment Tool), jehož obliba ve světě neustále roste.

Tento príspěvek má za cíl představit model SWAT, jehož užití na území České republiky je velmi vzácné, přestože má velký potenciál. Postupně je stručně popsán samotný model a následně je na př́kladu povodí vodní nádrže Olešná $\left(33 \mathrm{~km}^{2}\right)$, která slouží jako zdroj vody pro průmysl a značně trpí prísunem sedimentů a živin, provedena kalibrace a validace simulací průtoků pro denní časový krok a následné srovnání s měsíčním časovým krokem.

\section{MATERIÁL A METODIKA}

\section{Model SWAT}

Model SWAT je vytvářen především zásluhou Jeffa Arnolda na US Department of Agriculture Agricultural Research Service (USDA-ARS). SWAT je kontinuální model v měřítku povodí, který pracuje s denním časovým krokem a je vytvořen pro predikci vlivu managementu povodí na hydrologii, sedimenty a chemické látky spojené se zemědělskou činností, jako jsou živiny, pesticidy, těžké kovy a další.

SWAT vyžaduje poměrně podrobné údaje o půdě, informace o využívání půdy/hospodaření a výškopisná data. Mezi základní vstupní parametry pro půdu patří hloubka, zrnitostní složení, obsah organické hmoty a hydropedologické vlastnosti, a to především hydrologická skupina a nasycená hydraulická vodivost. Parametry Ize půdám přidělit zvlášt pro jednotlivé horizonty. Důležité parametry charakterizující typ využití půdy jsou čísla odtokových křivek pro jednotlivé hydrologické skupiny půd. Pro urbanizované plochy je navíc podstatný parametr podílu nepropustného povrchu. Pro zemědělsky využívané plochy je možnost parametrizace podrobného managementu zahrnujícího rotaci plodin, agrotechnické Ihůty setí, sklizně, orby, hnojení, pastvy apod. Výškopisná data slouží k odvození sklonitosti území, která je rozdělena do množství tříd podle uživatele. Dále Ize přidat další významné činnosti hospodaření např. bodové zdroje, odběry vody, zavlažování a další. Nejdůležitější vstupní klimatologická data jsou denní srážkové úhrny a minimální a maximální teplota vzduchu. Pokud jsou k dispozici podrobnější srážkové úhrny, Ize je využít. Další vstupní klimatologická data jsou úhrny globálního záření, relativní vlhkost vzduchu a průměrná rychlost větru. Ty jsou potřeba pro metody výpočtu evapotranspirace, které jsou náročnější na data. Hodnoty všech těchto veličin Ize simulovat pomocí stochastického generátoru počasí.

Proces výpočtu Ize rozdělit na část probíhající na úrovni krajiny a část představující procesy $v$ rámci hlavních vodních toků. Pro výpočet vodní bilance a následně odnosů jednotlivých látek na úrovni krajiny je plocha povodí rozdělena do dílčích subpovodí a dále do hydrologických odpovědních jednotek, tzv. HRU (Hydrologic Response Unit), tvořící kvazihomogenní plochy s unikátní kombinací typu půdy, krajinného pokryvu a třídy sklonitosti, které zachycují především rozdíly $\vee$ hodnotách evapotranspirace, stejně jako $v$ hodnotách odtoku pro jednotlivé HRU a rovněž pro jednotlivé plodiny. Základní procesy zahrnuty $\vee$ hydrologické bilanci povodí jsou obsaženy $v$ rovnici (1). K jednotlivým procesům existuje $\vee$ některých prípadech nabídka vícero matematických popisů hlavně v závislosti na náročnosti vstupních dat. Např́klad u výpočtu infiltrace srážek Ize použít metodu odtokových křivek, pro kterou postačují denní srážkové úhrny, nebo metodu Green\&Ampt, která vyžaduje srážky 


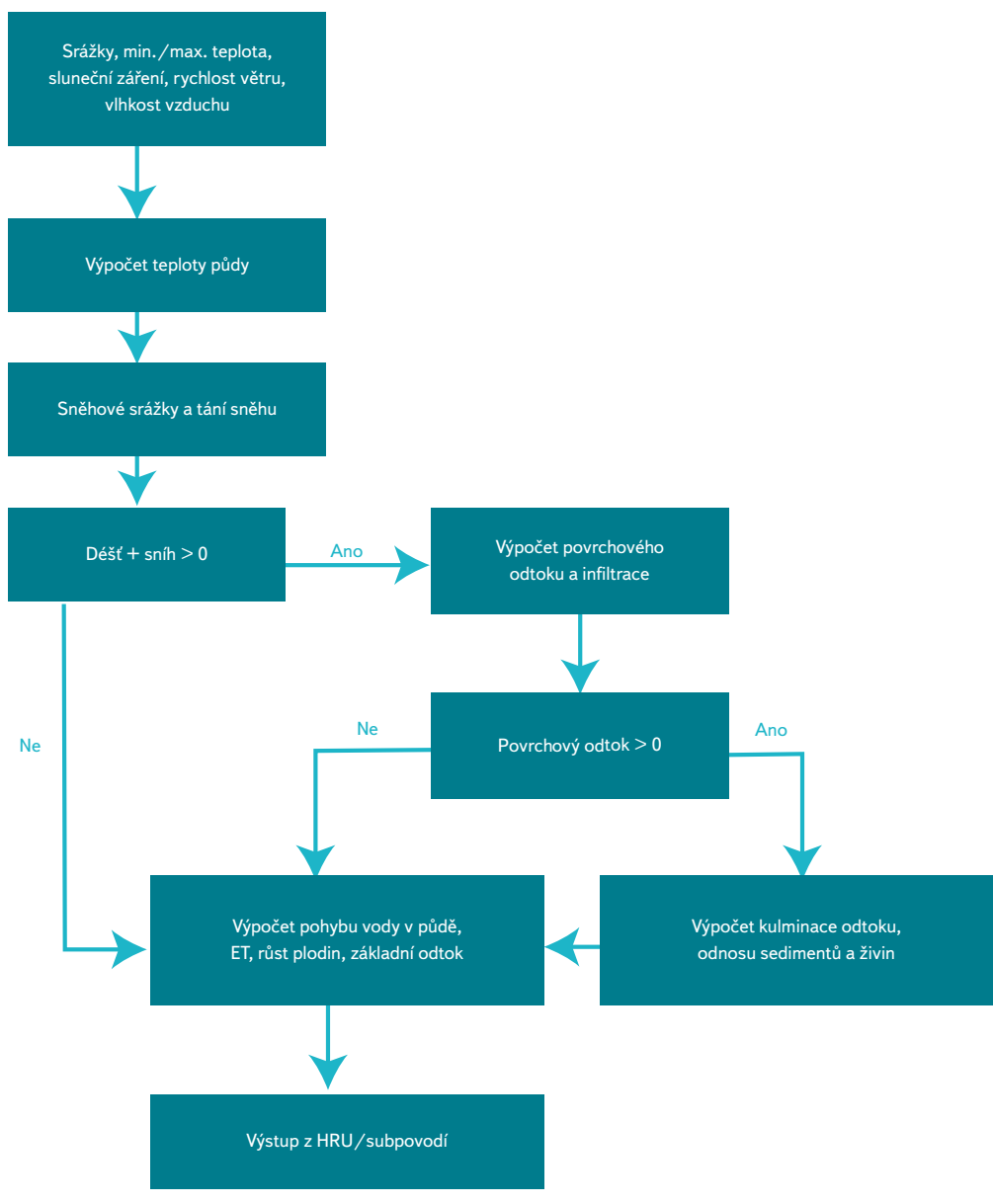

Obr. 1. Diagram postupu výpočtu hydrologické bilance v HRU/subpovodích

Fig. 1. Flowchart of hydrological budget calculation for HRU/subbasins

v podrobnějších časových intervalech. Podobně u výpočtu potenciální evapotranspirace Ize využít metody náročnější na meteorologická data, konkrétně Penmann-Monteith nebo Pristley-Taylor, ale zároveň metodu Hargreaves, která vyžaduje pouze údaje o teplotách. Odtok a koncentrace látek jsou potom modelovány odděleně pro každou HRU zvlášt’ a následně sloučeny do celkové hodnoty odtoku a koncentrace z plochy subpovodí podle diagramu na obr. 1.

$$
S W_{t}=S W_{0}+\sum_{i=1}^{t}\left(R_{d e n}-Q_{p o v}-E-W-Q_{p o d}\right)
$$

Kde SW je finální obsah vody v půdě,

$$
\begin{array}{ll}
S W_{0} & \text { obsah vody v půdě na počátku, } \\
R_{\text {den }} & \text { denní úhrn srážek, } \\
Q_{\text {pov }} & \text { povrchový odtok, } \\
E & \text { evapotranspirace, } \\
W & \text { infiltrace do vadózní zóny, } \\
Q_{\text {pod }} & \text { základní odtok. }
\end{array}
$$

Procesy probíhající na úrovni hlavních vodních toků představují transformaci vstupujícího odtoku vody, sedimentů, živin a dalších látek. Hlavní toky jsou zde schematizovány do homogenních kanálů s lichoběžníkovým profilem. Rychlost proudění vody je počitána přes manningovu rovnici a změna pomocí metod Variable storage nebo Muskingum. Například změna živin je počitána podle modelu QUAL2E.
Výstupy z modelu jsou na úrovni jednotlivých HRU, subpovodí a hlavních vodních toků v denním, měsičním nebo ročním časovém kroku. Pro HRU jsou ve výsledcích hlavně hodnoty vodní bilance (povrchový, podpovrchový a základní odtok, obsah vody v pưdě, potenciální a aktuální evapotranspirace atd.), dále např. množství biomasy, odnos sedimentů, bilance živin apod. Pro subpovodí se jedná o velmi podobné výsledky jako na úrovni HRU, kde dochází k jejich součtu. Na úrovni vodních toků jsou výsledkem vstupy ze subpovodí, co se týče vody, sedimentů a dalších látek a jejich transformace vodním tokem.

Vyčerpávající přehled o všech simulovaných procesech a jejich matematickém popisu, doporučeném použití apod. podává podrobná dokumentace k modelu [1].

Problém užití modelu SWAT v podmínkách České republiky spočívá hlavně

\begin{tabular}{|c|c|c|c|}
\hline Sklonitost & Typ & $\begin{array}{l}\text { Plocha } \\
\text { (ha) }\end{array}$ & $\begin{array}{l}\text { Relativní } \\
\text { zastoupení } \\
(\%)\end{array}$ \\
\hline & $0-7^{\circ}$ & 1045,84 & 31,44 \\
\hline & $7-17^{\circ}$ & 933,09 & 28,05 \\
\hline & $>17^{\circ}$ & 1347,70 & 40,51 \\
\hline \multicolumn{4}{|l|}{ Půda } \\
\hline & fluvizem oglejená & 84,63 & 2,54 \\
\hline & hnědozem luvická & 238,94 & 7,18 \\
\hline & pseudoglej modální & 274,3 & 8,24 \\
\hline & luvizem oglejená & 576,5 & 17,33 \\
\hline & kambizem oglejená & 240,39 & 7,23 \\
\hline & kambizem dystrická & 1591,97 & 47,85 \\
\hline & kambizem modální & 247,62 & 7,45 \\
\hline & vodní plochy & 72,33 & 2,17 \\
\hline \multicolumn{4}{|c|}{ Využití území } \\
\hline & orná pưda & 72,33 & 19,98 \\
\hline & travní porosty & 945,92 & 28,43 \\
\hline & křoviny & 128,33 & 3,86 \\
\hline & lesy & 1136,46 & 34,16 \\
\hline & souvislá zástavba & 0,92 & 0,03 \\
\hline & nesouvislá zástavba & 358,92 & 10,79 \\
\hline & dopravní stavby & 18,59 & 0,56 \\
\hline & vodní plochy & 72,68 & 2,18 \\
\hline
\end{tabular}
v nedostupnosti vstupních dat o půdách, což se týká především textury pưdy, obsahu organické hmoty a jejich hydropedologických vlastností a dále zemědělského managementu území, hlavně osevní postupy a užívaná agrotechnika. Databáze dostupné ke SWATu jsou tvořeny predevším pro území USA.

Tabulka 1. Zastoupení sklonitostních třid, puid a využití území ve vstupních datech Table 1. Composition of slope classes, soils and land use in input data 


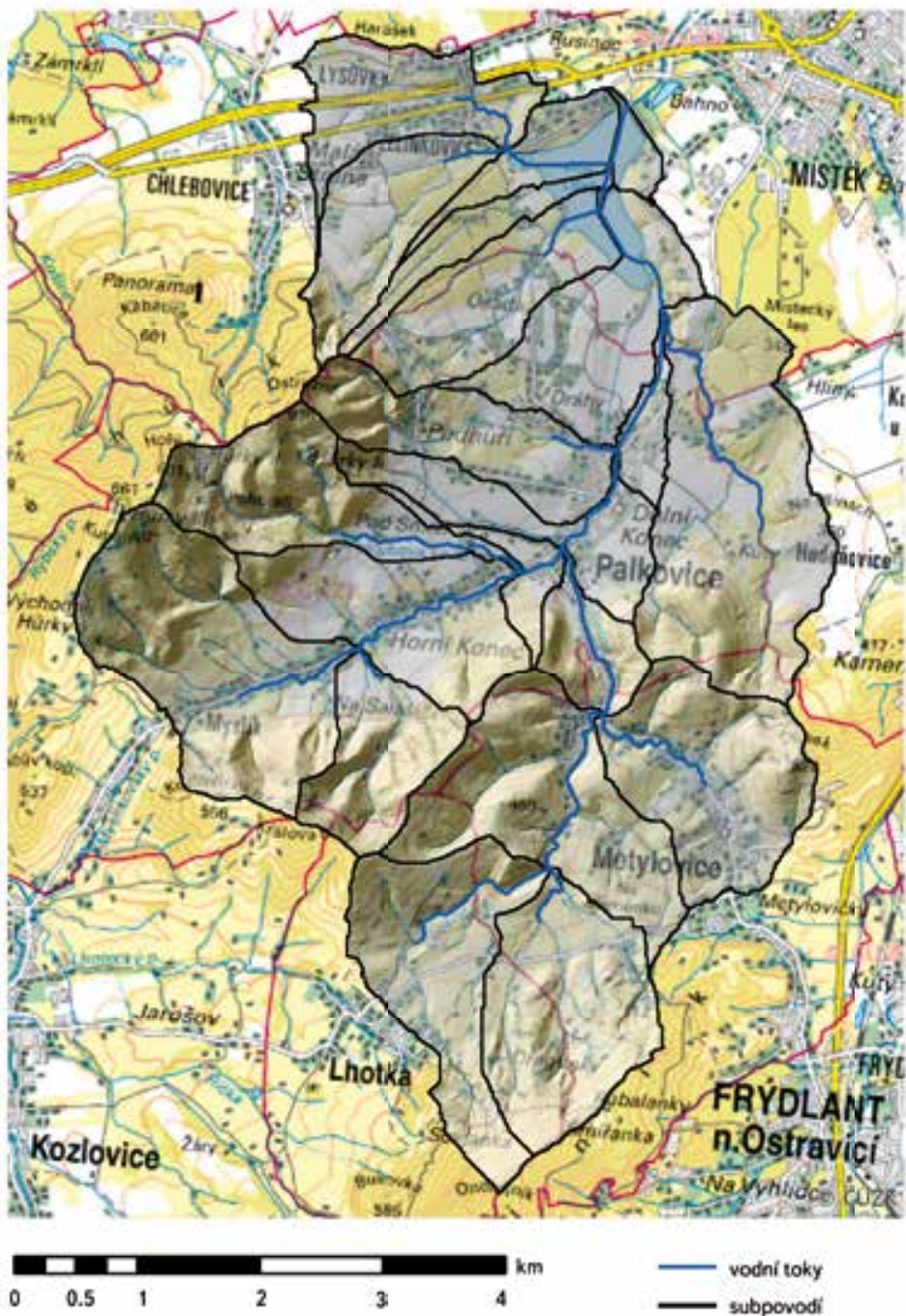

Obr. 2. Půdní typy, využití území a členění na subpovodí

Fig. 2. Soil types, land use and subbasins delineation

\section{Tvorba modelu}

Jako vstupní výškopisná data byl použit digitální model reliéfu 4. generace (DMR 4G) poskytovaný ČÚZK. Podle sklonitosti bylo povodí rozděleno na třídy $0-7^{\circ}, 7-17^{\circ}$ a nad $17^{\circ}$. Data o půdách byla odvozena predevším z komplexního průzkumu zemědělských půd provedeného $v 60$. letech minulého století. Rozložení půdních subtypů bylo převzato z půdních map a vlastnosti týkající se hloubek horizontů, zrnitosti, obsahu organické hmoty byly převzaty z výběrových sond vztahujících se $\mathrm{k}$ danému hospodářskému obvodu [2] a hodnoty pro lesní půdy byly převzaty z typologických půdních sond od ÚHUL. Hydropedologické vlastnosti, jako je nasycená hydraulická vodivost, byly odhadnuty podle pedotransferových funkcí [3]. Typ krajinného pokryvu byl odvozen interpretací ortofota pro dosažení lepšího rozlišení, než které poskytuje jinak hojně uživaná databáze Corine Land Cover, a management zemědělských ploch byl zjištěn na základě konzultace s agronomem podniku Beskyd Agro a. S., který hospodaří na značné ploše v povodí. Vstupní denní meteorologická data pochází z nejbližších měřicích stanic v rámci sítě ČHMÚ. Hodnoty min. a max. teplot, úhrnů zárení, relativní vzdušné vlhkosti a rychlosti větru pochází ze stanice v Mošnově. Hodnoty úhrnů srážek pochází ze čtyř srážkoměrných stanic.
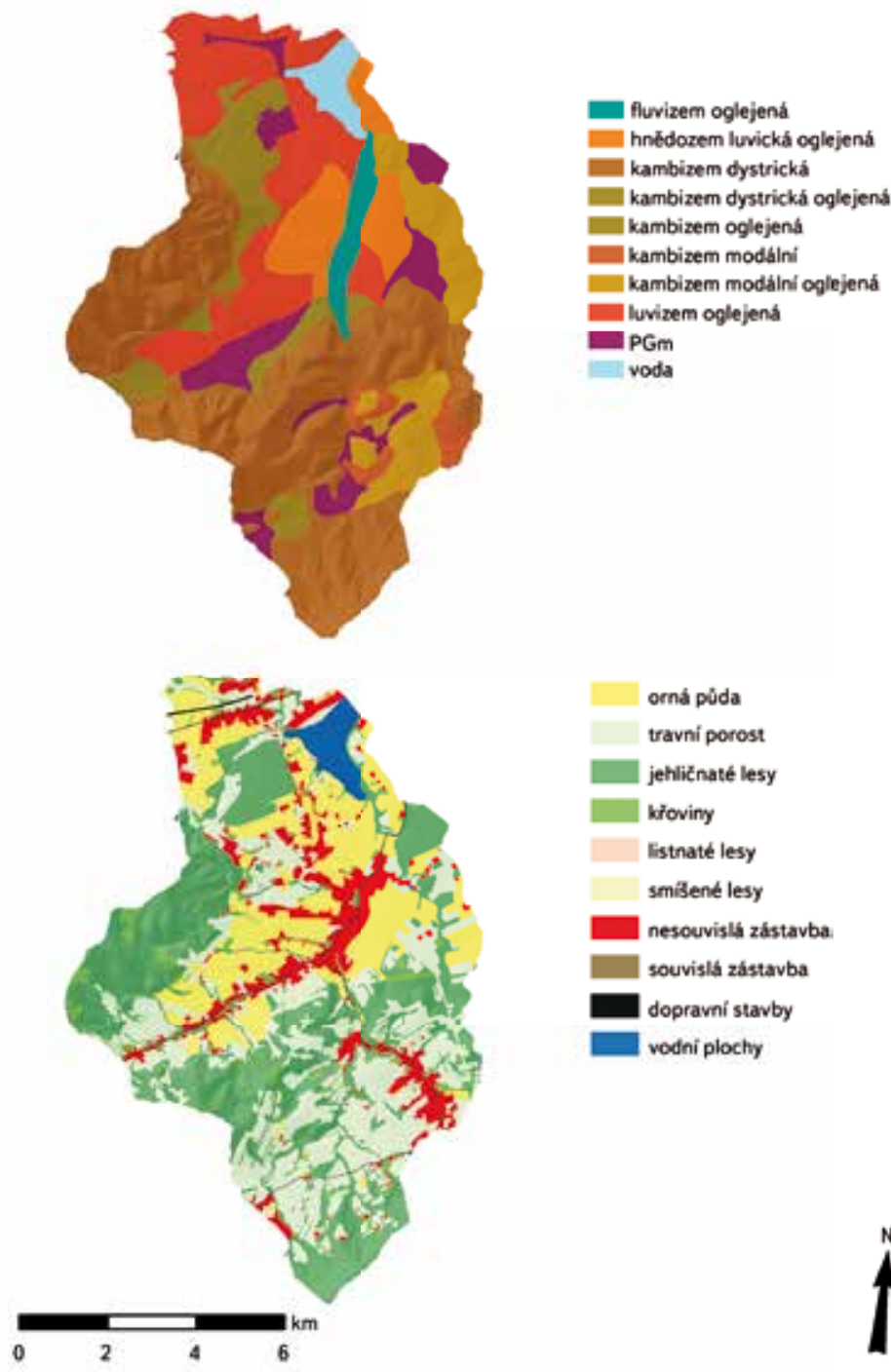

Samotná diskretizace povodí na subpovodí a HRU proběhla v prostředí programu Quantum GIS s využitím zásuvného modulu QSWAT [4]. Celkově bylo povodí rozděleno na 21 subpovodí a $1102 \mathrm{HRU}$

Jak je patrné z tabulky 1, využití území povodí je spojeno především se zemědělskými plochami a lesy. Orná půda je situována především na luvizemích, hnědozemích a pseudoglejích. Mezi nejvíce pěstované plodiny zde patří řepka, kukuřice, ozimá pšenice a ozimý ječmen. Na kambizemích pak převládá využití jako travní porosty, nejčastěji louky a v menší míře pastviny a ve vyšších polohách lesy. Plošné rozložení zobrazují mapy na obr. 2.

\section{Kalibrace modelu}

Pro kalibraci vybraných parametrů byly výsledky simulací průtoků porovnány s měřenými řadami z vodoměrné stanice v obci Palkovice (poskytuje ČHMÚ) a z bilančních prítoků do VD Olešná (poskytuje státní podnik Povodí Odry) v denních a měsíčních průměrných hodnotách. Užití těchto dvou typů dat vnáší do kalibrace parametrů odlišnou nejistou vzhledem k rozdílnému původu (průtoky ČHMÚ podle vodních stavů přepočteny přes měrné křivky, Povodí Odry 
pak podle bilance mezi odtokem a kolísáním vody v nádrži). Pro kalibraci modelu bylo zvoleno období mezi roky 2007 a 2011 a pro validaci modelu, tedy ověření výkonnosti modelu na časové řadě meteorologických dat, období 2012 až 2015. Zvolené vstupní parametry byly adjustovány automaticky algoritmem SUFI-2 (Sequential Uncertainty Fitting) implementovaným v programu SWAT-CUP [5]. Změna parametrů byla umožněna bud" úplnou změnou hodnoty, což se týká hlavně konstant, nebo relativní změnou. Hodnoty změn jsou v rámci algoritmu vzorkovány metodou latinských čtverců. Jako objektivní funkce byl zvolen nejrozšiřrenější vzorec $\vee$ hydrologii Nash-Sutcliffe Efficiency NSE (rovnice (2)) pro porovnání výsledků simulací a pozorovaných dat.

$$
N S E=1-\frac{\sum_{t=1}^{T}\left(Q_{s i m}^{t}-Q_{o b s}^{t}\right)^{2}}{\sum_{t=1}^{T}\left(Q_{o b s}^{t}-\overline{Q_{o b s}}\right)^{2}}
$$

Kde

$$
\begin{array}{ll}
Q_{\text {sim }} & \text { je simulovaný průtok, } \\
Q_{\text {obs }} & \text { pozorovaný průtok. }
\end{array}
$$

\section{VÝSLEDKY A DISKUSE}

Cílem studie bylo na základě měřených průtokových řad provést kalibraci a validaci modelu, a tím prověřit funkčnost modelu SWAT na príkladu povodí VN Olešná.

Byla provedena automatická kalibrace vybraných důležitých parametrů, na něž jsou výstupy modelů citlivé. Jejich hodnoty ukazuje tabulka 2. Velký vliv zde mají parametry spojené se základním odtokem s hodnotami odpovídajícími povodím s rychlou odezvou, což odpovídá předpokladu na základě převládajícího karpatského flyše v geologickém podloží [6]. Potřeba snížit hodnoty odtokových křivek může být částečně způsobena přitomností plošných odvodňovacích staveb, které snižují pravděpodobnost vzniku povrchového odtoku. Př́tomnost takovýchto staveb Ize do modelu zahrnout, nicméně nejsou k dispozici př́liš podrobné informace o jejich umístění a parametrech.

\section{Tabulka 2. Kalibrované hodnoty parametrů modelu}

Table 2. Calibrated model parameters values

\section{Parametr}

\section{Kalibrovaná hodnota}

\begin{tabular}{ll}
\hline recesní konstanta základního odtoku & 0,93 \\
\hline hydraulická vodivost koryta hl. vodního toku [mm·h'] & 63 \\
\hline délka pro podpovrchový odtok [m] & 43,24 \\
\hline zpoždění základního odtoku [dny] & 1,19 \\
\hline Čísla odtokových křivek & $-17 \%$ \\
\hline mezní hloubka podzemní vody pro základní odtok [mm] & 881 \\
\hline kompenzační faktor pro evapotranspiraci & 0,93 \\
\hline manningova drsnost hl. vodního toku & 0,05
\end{tabular}

$\checkmark$ hodnocení modelu při kalibraci model simuluje průtoky v denním kroku s větší úspěšností po stanici v Palkovicích, přičemž v měsičním kroku se tento rozdíl smazává (tabulka 3). Hodnota NSE je poměrně citlivá na shodu při velkých průtocích, které se $v$ denním kroku při vstupu denních úhrnů srážek obtížně predikují, především právě na menších povodích. Nejvíc je tento problém patrný pro květen roku 2010 s výskytem přibližně pětiletého průtoku, kde dochází k největšímu podhodnocování, a to dokonce o více než 50 \%. V denním kroku je ve SWATu použita metoda odtokových křivek, která nemůže bez zohlednění intenzity srážek mnohdy adekvátně vypočíst výšku infiltrace [7]. Toto negativum se přestává projevovat s rostoucí plochou povodí.

Tabulka 3. Hodnoty NSE pro období kalibrace a validace

Table 3. NSE values for calibration and validation

\begin{tabular}{lllll} 
& Kalibrace & \multicolumn{3}{c}{ Validace } \\
\hline Stanice & denní & měsíční & denní & měsíční \\
\hline Palkovice & 0,71 & 0,89 & 0,63 & 0,8 \\
\hline VN Olešná & 0,49 & 0,89 & 0,42 & 0,8
\end{tabular}

I po shlazení do měsíčního kroku zůstává část neshody, která souvisí především se zimními a jarními měsíci (obr. 3). Model zde tedy hưře předpovídá procesy spojené s tvorbou sněhové pokrývky a následným odtáváním. Přesto se citlivost změny parametrů spojených s procesy ohledně sněhu na změny hodnot NSE neukázala jako významná. Větší vliv na NSE má srovnání vysokých průtoků $v$ letních měsících, které dosahují vyšších kulminačních hodnot. $V$ rámci doporučených kritérií pro hodnocení na základě NSE Ize konstatovat, že model produkuje velmi dobré výsledky [8]. Pravděpodobně bude potřeba pro objektivní funkci zvolit jiný vztah než tradiční NSE, který je citlivějši i k nižším hodnotám průtoků, např. Kling-Gupta Efficiency (KGE) [9], což je hodnota vycházející z rozkladu NSE, nebo hledat optimum napříč více mírami výkonnosti. Nejkorektnějším řešením je pak užití tzv. ekvifinálních modelů, tedy nepoužívat model s jednou konkrétní sadou parametrů, ale se všemi, které produkují rozumné výsledky.

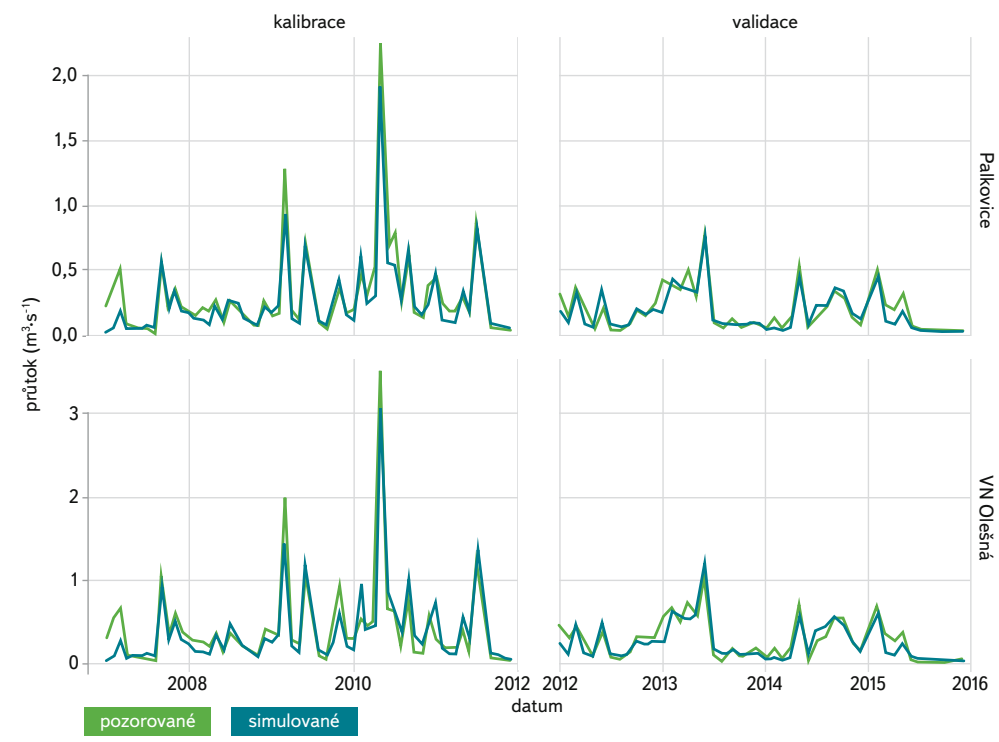

Obr. 3. Porovnání simulovaných a pozorovaných měsičních průtoků

Fig. 3. Comparison of simulated and observed monthly flows

\section{ZÁVĚR}

Model SWAT, který je vyvíjen v USA, již získal popularitu napříč světem, přesto je $v$ České republice jeho užití ojedinělé. Jeho užití je limitováno často špatnou dostupností vstupních dat o vlastnostech půd a managementu území. Na příkladu povodí k VD Olešná byl proveden sběr potřebných dat na základě 
dostupných zdrojů a bylo provedeno ověření výkonnosti modelu v předpovědi průtoků po kalibraci modelu. Výstupy v denním kroku se ukázaly jako problematické především při intenzivnějších srážkových událostech, u kterých nelze adekvátně vypočíst proces infiltrace, který v prípadě menších povodí nabývá na významnosti. $\vee$ rámci validace oproti kalibraci pak výkonnost ještě klesá. Výsledky simulací v měsíčním kroku vycházejí velmi dobře konzistentně i v rámci validace.

Model bude dále kalibrován hlavně pro zpřesnění procesů spojených se sněhovou pokrývkou adjustací relevantních parametrů tak, aby i v denním kroku adekvátně predikoval hydrologickou bilanci. Následně bude provedena kalibrace a validace procesů spojených se živinami podle měřených dat koncentrací dusičnanového dusíku a celkového fosforu, pouze v měsičním kroku (malá frekvence měření), což představuje další výzvu, hlavně pro další zpřesňování managementu povodí. Takovýto model dále poslouží k prognóze dopadu potenciálních klimatických změn a efektivity adaptačních opatření.

\section{Poděkování}

Př́spěvek vznikl za podpory interního projektu Ostravské univerzity SGS05/PřF/20172018 Poznání vývoje a současného stavu krajiny Západních Karpat a východo-sudetských pohořís ohledem na činnost člověka a současných prírodních hazardů.

\section{Literatura}

[1] NEITSCH, S.L., ARNOLD, J.G., KINIRY, J.R., and WILLIAMS, J.R. Soil and water assessment tool theorethical documentation, 2009, p. 618

[2] VúMOP. Komplexní průzkum půd - webová aplikace [online], [vid. duben 2018]. Dostupné z: http://geoportal.vumop.cz/index.php?page=kpp

[3] SAXTON, A. and ROWLS, W. Soil Water Characteristic Estimates by Texture and Organic Matter for Hydrologic Solutions. Soil Science Society of America Journal, 2006, vol. 70, p. 1569-1578.

[4] DILE, Y.T., DAGGUPATI, P., GEORGE, CH., SRINIVASAN, R., and ARNOLD, J. Introducing a new open source GIS user interface for the SWAT model. Environmental Modelling and Software, 2016, vol. 85, p. 129-138.

[5] JAJARMIZADEH, M., HARUN, S. ABDULLAH, R, and MOHSEN, S., Using Soil and Water Assessment Tool For Flow Simulation and Assessment Of Sensitive Parameters Applying SUFI-2 Algorithm. Caspian Journal of Applied Sciences Research, vol. 2, p. 37-44.

[6] GAÁL, L., SZOLGAY, J., KOHNOVÁ, S., PARAJKA, J., MERZ, R., VIGLIONE, A., and BLÖSCHL, G. Flood timescales: Understanding the interplay of climate and catchment processes through comparative hydrology. Water Resources Research, 2012, vol. 48, p. 1-21.

[7] YANG, X., LIU, Q., HE, Y., LUO, X., and ZHANG, X. Comparison of daily and sub-daily SWAT models for daily streamflow simulation in the Upper Huai River Basin of China. Stochastic Environmental Research and Risk Assessment, 2016, vol. 30, No. 3, p. 959-972.

[8] MORIASI, D.N., ARNOLD, J.G., VAN LIEW, M.W., BINGER, R.L., HARMEL, R.D., and VEITH, T.L. Model evaluation guidelines for systematic quantification of accuracy in watershed simulations. Transactions of the ASABE, 2007, vol. 50, No. 3, p. 885-900

[9] GUPTA, H.V., KLING, H., YILMAZ, K.K., and MARTINEZ, G.F. Decomposition of the mean squared error and NSE performance criteria: Implications for improving hydrological modelling Journal of Hydrology, 2009, vol. 377, p. 80-91.

\section{Autor}

Mgr. et Mgr. Petr Krpec

凶petr.krpec@osu.cz

Ostravská univerzita, Katedra fyzické geografie a geoekologie

\section{DISCHARGE PREDICTION BY SWAT MODEL} IN CASE OF OLEŠNÁ WATER RESERVOIR

\section{KRPEC, P.}

University of Ostrava, Department of Physical Geography and Geoecology

Keywords: SWAT model - input data - Olešná reservoir calibration and validation

Mathematical models have been used in hydrology for decision making support for many years. They allow the realization of virtual experiments that can be done empirically either very difficult or not at all. The SWAT model, developed in the US, has gained world wide popularity but its application in the Czech Republic is quite rare yet. Its application is limited often by lack of aviable input data about soil properties and land management. On the example of the Olešná reservoir watershed, the necessary data was collected on the basis of the available sources and the model performance was verified in the flow forecast after the model calibration. Outputs in the daily step proved to be problematic especially in the case of more intense rainfall events, where the infiltration process, which in the case of smaller basins, can not be adequately calculated using just daily precipitations. The outputs of the simulations in the monthly step are assessed as very good and consistent in validation.

Příspěvek prošel lektorským řízením. 